\section{ALEXANDER GRAHAM BELL AND THE INVENTION OF THE TELEPHONE*}

\author{
By Prof. G. W. O. HOWE
}

\begin{abstract}
A LEXANDER GRAHAM BELL was born in South Charlotte Street, Edinburgh, on March 3, 1847, the son of Alexander Melville Bell, who was a lecturer in elocution at the University, and whose father, Alexander Bell, was also a prominent teacher of elocution. This Alexander Bell had been a shoemaker in St. Andrews, but had removed to Edinburgh and taken up acting, giving public readings of Shakespeare's plays, and correcting stammering and other defects of speech. He then set up in London as a teacher of elocution.
\end{abstract}

In 1865, on the death of his father, Melville Bell removed from Edinburgh to London, leaving his Edinburgh pupils and business in the hands of his eldest son, Melville James. Melville Bell was appointed lecturer in elocution at University College. He was probably best known for his work on visible speech, that is, a method of teaching congenital deaf-mutes to speak, and it has been said that Miss Helen Keller is a living monument to his work.

Melville Bell had three sons, of whom Alexander Graham was the second. On leaving Edinburgh High School at the age of fifteen, Alexander Graham went for a year to Elgin as a pupil teacher; he then attended lectures in Greek and Latin at the University of Edinburgh for a year, and at seventeen returned to Elgin as a resident teacher of elocution and music. In 1867 his younger brother died of tuberculosis at the age of nineteen, and Alexander Graham took a post at Bath to be nearer his parents, going the following year to London to be his father's assistant and deputizing for him during his visits to America. $\mathrm{He}$ also attended classes in anatomy at University College. Then the elder brother in Edinburgh died suddenly, and as Alexander Graham's health was causing great anxiety, Melville Bell decided to leave London and settle in Brantford, Ontario. This was in 1870, and in the same year he was appointed professor of elocution at Queen's College, Kingston, Ontario. It will be seen that Alexander Graham Bell was born and brought up in an atmosphere of vocal physiology and phonetics. At their father's instigation, he and his elder brother, when schoolboys, had made a model of the mouth and vocal organs in gutta-percha and india-rubber, and operated the lips and tongue while blowing air through it. If it did not speak, it is at least reported to have made a very passable imitation of 'Ma-ma'.

While teaching in Elgin, Alexander tried to determ. ine the pitch of the tones that constitute the various vowel sounds and the resonance pitches of the mouth cavities when shaped to pronounce a given vowel sound. He wrote a forty-page letter to his father about it, and his father consulted his friend Alexander J. Ellis, who later translated Helmholtz's "Sensations of Tone"; Ellis pointed out that Helmholtz had already done the same thing much more thoroughly and had also synthesized the vowel sounds by means of vibrating forks. Bell tried to repeat his experiments, but he confessed afterwards that his knowledge of the laws of electricity was too slight to enable him to understand the explanations given. Ellis

* Substance of a commemorative address before the Royal Society of Edinburgh on March 3. lent him the book, but as it was in German, Bell could only study the diagrams and try to interpret them. One of his misunderstandings was very fortunate, for he gathered that Helmholtz had sent vowel sounds by telegraph, and it was two or three years before he found out his mistake. His mind started working on such things as the production of music by a number of electrically maintained forks operated by keys, and the possibility of transmitting the music over wires to a distance where there could be an electrically operated piano. He also thought. of transmitting Morse signals by interruption of the musical note. He studied the various systems of telegraphy then in use and became familiar with Morse keys, sounders, etc.

After a year or two in Canada, his health was greatly improved, and he was invited by the Boston Board of Education to investigate the possibility of teaching the children in the school for deaf-mutes to speak by means of his father's system. He spent several months in a number of such schools in New England, and in October 1872 he settled in Boston as a teacher of visible speech, and in the following year was appointed professor of vocal physiology in the School of Oratory of the University of Boston. He was then twenty-six years of age and an elocutionist of the third generation.

Whatever else he might be doing, Bell devoted his spare time to experiments, and in 1874 he had a young instrument maker, Thomas A. Watson, make him a number of electromagnets each with a flat spring armature, one end of the spring being clamped on one pole and the other end free to vibrate over the other pole; those that were to be used as transmitters having make-and-break points like an electric bell. There were six or eight transmitters, all tuned to different frequencies by adjusting the springs and connected to the same number of distant receivers through a single telegraph wire. Each receiver was tuned to its appropriate transmitter and was expected to respond to no other, but to reproduce the dots and dashes by an intermittent tone having a certain pitch. Bell never succeeded in getting this so-called harmonic telegraph to work satisfactorily.

Although he devoted himself whole-heartedly to the development of this harmonic telegraph, he had the transmission of speech always at the back of his mind and discussed it occasionally with his assistant, Watson; but his future father-in-law, who was helping him financially, persuaded him to concentrate on the harmonic telegraph.

In June 1874 he gave an address to a convention of teachers of articulation to the deaf and dumb at Worcester, Mass., and demonstrated to them two instruments with which he did much experimenting. One was the manometric capsule of Koenig, which enabled a deaf person, by watching a sensitive flame in a rotating mirror, to note and try to imitate the wave-forms of the various vowel sounds. The other was Leon Scott's phonautograph, in which the membrane operated a bristle which traced the wave on a moving glass plate coated with lamp black. All this shows clearly that, to Bell, speech and waveform were almost synonymous.

In February 1875 he went to Washington in connexion with patent applications for multiple telegraphy, and took the opportunity of calling upon Joseph Henry, who was secretary of the Smithsonian Institution, and was then seventy-six. He explained his idea of an articulate telephone; Henry told him that he thought it the germ of a great invention and 
advised him to work at it and not publish the idea. When Bell said that he felt that he had not the necessary electrical knowledge, Henry replied, "Get it." In a letter to his parents, Bell said, "I cannot tell you how those two words have encouraged me." Little did Henry and Bell dream as they sat talking that they would both, one day, be members of that small group of immortals-Ampère, Volta, Watt, Ohm, Faraday, Maxwell, Joule-whose names are for ever enshrined in the nomenclature of science.

It was on June 2, 1875, that something occurred which altered the whole course of events. Watson was in one room attending to the transmitting reeds, while Bell in an adjacent room put each receiving reed in turn against his ear and adjusted it until it was properly tuned to its respective transmitter. Suddenly Bell rushed in to see what was happening and, as Watson said, "the speaking telephone was born at that moment." What had happened was simply that the make-and-break points of one reed had welded together, and Watson had been plucking the reed to try to restart it, with the result that the sound that Bell heard was entirely changed. He saw at once that the receiver was being actuated, not by an intermittent current, but by an undulatory current in a closed circuit produced by the vibrations of the steel spring over the pole of the electromagnet due to the plucking. He told Watson to make a small drumhead of gold-beater's skin, with the centre joined to the free end of the steel spring by means of a small button of cork, and a mouthpiece over the drumhead. This was made at once and tested the following evening, but the results were not very successful. Although Watson could hear Bell's voice and almost eatch the words, it required nine months further experimenting before Watson heard a complete and intelligible sentence. His patent application was filed on February 14, 1876, and the patent was granted on March 7. At that time a complete sentence of intelligible speech had not been transmitted, but a few days later, on March 10 , Bell was trying his liquid transmitter in which the diaphragm carried a metallic wire dipping into a cup of acidulated water, and Watson heard the first complete sentence ever transmitted by the telephone. It was "Mr. Watson, come here; I want you." Contrary to the common fallacy that Bell only invented the electromagnetic telephone, claim 4 of his patent specification is for "the method of producing undulations in a continuous voltaic circuit by gradually increasing and diminishing the resistance of the circuit, or by gradually increasing and diminishing the power of the battery, as set forth".

During the summer of 1876 much progress was made, and by October tests were being made between Boston and Cambridge, a distance of two miles. Experiments were made with diaphragms of several feet diameter and with diaphragms as small as that of the human ear, with electromagnets and with permanent magnets of all shapes and sizes, and the present type of receiver gradually emerged. Bell used it both as receiver and transmitter; but it was necessary to speak very loudly in order to obtain satisfactory reception. The liquid transmitter was obviously not very suitable for practical use.

A very interesting coincidence occurred in connexion with Bell's patent application. He did not wish to make the American application until a similar application was lodged in London, and a friend who was going to London took a copy of the application and promised to send Bell a cable as soon as it was lodged. The cable never came and the application remained at the bottom of his friend's trunk. On February 14, 1876, his future father-in-law decided to wait no longer and lodged the application in Washington without consulting Bell. This was a fortunate decision, for an hour or two later on the same day Elisha Gray lodged a caveat which also described a liquid transmitter with an electromagnetic receiver. Another interesting point is that fifteen days after the patent was lodged, Bell altered the wording by substituting "gradually increasing and diminishing the resistanae", for "alternately increasing and diminishing the resistance". This was doubtless intended to emphasize the undulatory nature of the current, which is stressed throughout the specification.

Within a few months Bell exhibited a liquid transmitter as well as the electromagnetic transmitter and receiver at the Philadelphia Centennial Exhibition. One of the judges at this exhibition was Sir William Thomson, afterwards Lord Kelvin, and in his address to the British Association in Glasgow on his return he said: "T heard "To be, or not to be. There's the rub' through an electric telegraph wire, but scorning monosyllables, the electric articulation rose to higher flights and gave me messages taken at random from the New York newspapers. All this my own ears heard. This, the greatest by far of all the marvels of the electric telegraph, is due to a young countryman of my own, Mr. Graham Bell. Who can but admire the hardihood of invention which devised such very slight means to realize the mathematical conception that, if electricity is to convey all the delicacies of quality which distinguish articulate speech, the strength of the current must vary continuously and as nearly as may be in simple proportion to the velocity of a particle of the air constituting the sound." This was in June 1876, only four months after the lodging of his patent application. Sir William asked for the apparatus to be removed to the Judges' Hall for further tests, as he wanted Lady Thomson to hear it. It is interesting to know that Henry was also one of the judges and reported that Bell's invention was "the greatest marvel hitherto achieved by the telegraph".

The first outdoor telephone line was installed in Boston in 1877, and at that time Bell gave a number of lectures in New York and in most of the large cities of New England, at which demonstrations were given of telephone reproduction of distant singers and speakers. In August of the same year, Bell married and made a trip to England and Scotland. On October 31, 1877, he gave an address in London on "Researches in Electric Telephony", at a special meeting of the Society of Telegraph Engineers (now the Institution of Electrical Engineers). He concluded by saying that conversations had been carried on between New York and Boston, and that Mr. Preece, the engineer-in-chief to the Post Office, had informed him that conversations had been successfully carried on through a submarine cable between Dartmbuth and Guernsey. Mr. and Mrs. Bell stayed eighteen months in Britain. Bell was kept busy, lecturing and clearing up the patent muddle caused by his friend's neglect to lodge the application in London before Sir William Thomson's return from America and his publication of all the details.

As an indication of the rapid appreciation of Bell's work and of the remarkable development of the telephone on the commercial side, the Western Union 
Telegraph Company declined the offer of Bell's father-in-law to sell all the Bell patents for 100,000 dollars; this was early in 1876. Two years later it was said that the Company would gladly have given $25,000,000$ dollars for them.

Bell's idea of using the same instrument as receiver and transmitter proved unsatisfactory because of its lack of sensitivity, and his company soon went over to the use of transmitters of the variable resistance type, acquiring the Blake transmitter in October 1878. In 1879 an agreement was made between the Western Union Company and the Bell Company whereby the latter had the use of the patents of Gray, Edison, Dolbear, and others, owned by the former company, who agreed that Bell was the inventor of the telephone and that his patents were valid and covered such things as transmitters using carbon contacts. But patent litigation went on for many years, the total number of actions involving the Bell patents reaching about six hundred. The great value of Bell's invention can be judged from the number and violence of the attacks made upon it, and its soundness from the complete failure of all the attacks.

On November 24, 1937, a tablet was unveiled on the house in which Alexander Graham Bell was born, and in the address following the function, I mentioned that it might be asked whether the statement that he was the inventor of the telephone was justified. Have not other men been given the credit for the invention? In accounts of early experiments one must not be misled by the use of the word telephone ; it was used by Wheatstone and others before Bell was born, for the purely mechanical transmission of sound. The transmission of tones by means of an electric circuit was sometimes referred to as electric telephony; and finally, when speech transmission was attained, it was sometimes distinguished as articulate telephony or speech telephony.

The starting point of all the early experimenters segmed to be the phenomenon of magnetostriction discovered in 1837 by Page, and described by him in Silliman's Journal under the title of "The Production of Galvanic Music". If a coil is wound around an iron rod, then the rod emits a sound when the current is switched on and a louder sound when the circuit is suddenly opened. If the current is interrupted at an audible frequency, the rod will emit a musical tone, which can be amplified by mounting the rod on a sounding board. By varying the frequency of the interruptions the rod can be made to "sing a tune'.

The late Silvanus Thompson wrote a book entitled "Philipp Reis, the Inventor of the Telephone". As I said in 1937, I read and re-read this book, and it removed any doubts which I may have had as to the justification for regarding Bell as the inventor of the telephone. Reis was a school teacher living near Frankfort-on-Main, who devoted years of patient research to the problem of telephony; he read papers and gave demonstrations at Frankfort and other places. After 1864, no further progress appears to have been made; the matter was allowed to drop, and Reis died in 1874. Thompson visited his home and interviewed his widow and others who had known Reis and taken part in his experiments ; but there is no reliable evidence that Reis ever succeeded in transmitting a single sentence of intelligible speech. His transmitter was essentially a make-and-break apparatus, capable of transmitting tones and therefore tunes, and very simple vocal sounds. It consisted of a box with a mouthpiece into which one spoke; on the top of the box was a membrane carrying a thin strip of platinum; an arm carried a fine platinum point which was adjusted to touch the platinum strip on the membrane. His receiver was the singing iron rod of Page, mounted on a sounding board, which would respond to the make and break. In the light of our present knowledge-or even of the knowledge of the nature of speech which Bell possessed in 1875-it is obvious that such a makeand-break device could not possibly transmit intelligible speech.

A book entitled "Who Invented the Telephone ?", by William Aitken, was published in 1939. It consists in the main of a very crude attack on Bell. It purports to give a reproduction of Bell's patent specification "somewhat abbreviated". On reading it, I wondered if Bell had really made such a muddled statement, but on consulting the actual specification I found it to be crystal clear; the apparent muddle was due entirely to the omission of an essential phrase.

Everyone who came into personal contact with Bell was impressed by his transparent honesty and his readiness to give due eredit to other people, so much so that the Bell Company lawyers found it rather disconcerting. On returning from England in 1878 , he was so tired of the patent squabbles and the prospect of having to fight unscrupulous rivals, that he decided to give it all up and return to teaching; but Watson, who was sent to Canada for the purpose, persuaded him to return with him to Boston and do his best to defend his patent rights.

For the next year or two he experimented with selenium and the problem of producing and reproducing sound by the agency of light-the photophone as he called it. In 1880 the French Government awarded him the Volta Prize of 50,000 francs which had been established by Napoleon. With this money he established in Washington the Volta Laboratory, and financed experimental work in which he was associated with his cousin, Chichester Bell, and Sumner Tainter. It was this Volta Laboratory Association that made the great advances in the gramophone, replacing Edison's hill-and-dale recording on tin foil by lateral cutting on a wax cylinder and later replacing the cylinder by a disk. When these patents were sold, Bell put his share of 200,000 dollars into the endowment of a Volta Bureau for the increase and diffusion of knowledge relating to the deaf.

In 1885 the Bell family visited Baddeck, in Nova Scotia, and were so pleased with it that Bell gradually acquired land there until he owned a headland which he called Beinn Bhreagh, on which he built a house and a laboratory. This was in 1892. For the remaining thirty years of his life his main interests were sheep breeding and aerial flight. In 1907 he formed an Aerial Experimental Establishment and gathered around him a group of experts. They experimented with man-carrying kites, aeroplanes and hydrofoils.

It was a memorable occasion when in 1915 the coast-to-coast telephone service was opened by Bell in New York and his old assistant Watson in San Francisco, a distance of 3,400 miles.

Bell died at his home in Nova Scotia on August 2, 1922 , and was buried on the hilltop at Beinn Bhreagh. The coffin of pine boards was made in the laboratory workshop, and he was dressed in an old homespun working suit with the red button of the Legion of Honour in his buttonhole. 